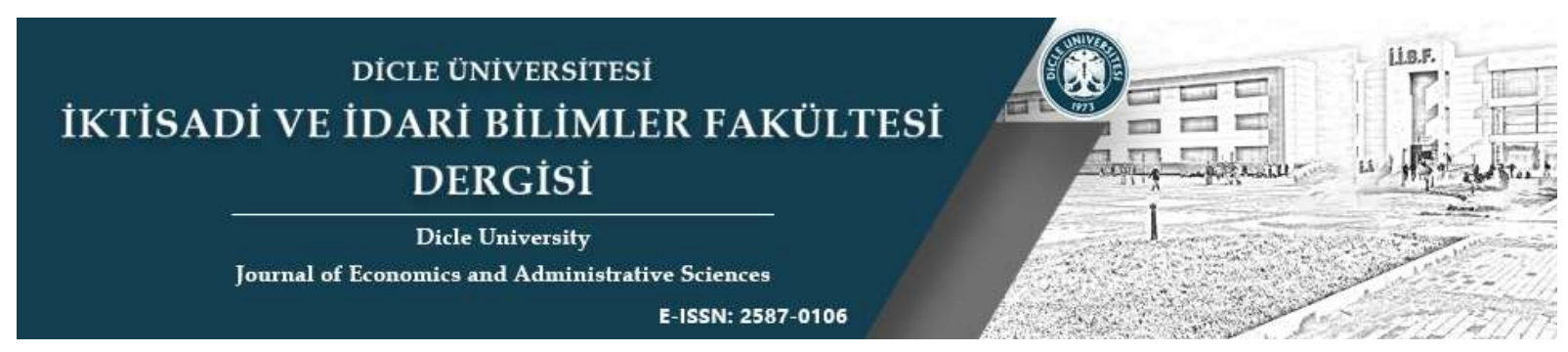

Cilt / Volume: 11, Sayı / Issue: 22, Sayfalar / Pages: 594-612

Araştırma Makalesi / Research Article

Received / Alınma: 29.07.2021

Accepted / Kabul: 08.10.2021

\title{
AFET VE KRİZ YÖNETIMININ ŞANLIURFA İLİ AÇISINDAN İNCELENMESİ
}

\author{
Ömer Faruk BİLBAY ${ }^{1}$ \\ Gülben ÇELIKK BOZKAYA²
}

$\ddot{\boldsymbol{O}} z$

Günümüzde doğal ve beşerî faktörlere bağlı olarak yaşanan afet olayları dünya gündeminde yer alan konuların başında gelmektedir. Nitekim ülkemizde gerek bulunduğu coğrafi konum gerekse iklim değişikliği, salgın olaylar, çevre sorunları, çarpık kentleşme, denetim yetersizliği, konut güvenliği, alt yapı yetersizliği gibi beşeri faktörlere bağlı olarak afet olayları sık sık yaşanmaktadır. Afetlerin türü ve boyutu afetin meydana geldiği bölgenin coğrafi yapısı, gelişmişlik düzeyi, afet bilinci gibi faktörlere göre değişiklik gösterebilmektedir. Bu bakımdan Şanlıurfa ilimiz bulunduğu konum, sosyoekonomik yapısı ve iklim koşulları açısından incelenmesi gereken illerimizin başında gelmektedir. Şanlıurfa deprem bölgesinde yer almamasına rağmen çevre illerde meydana gelen depremlerden, kışın artan sel ve taşkın olaylarından, yaz aylarında aşırı kuraklık olaylarından etkilenmektedir. Ayrıca en fazla sığınmacıya sahip iller arasında olmasıyla birlikte sığınmacıların uyum sorunu, kültürel çatışma, kentsel güvenlik bakımından incelenmesi gereken iller arasında yer almaktadır. Şanlıurfa'da afet olaylarının sosyal ve yönetim açısından bir krize dönüşmeden sorunların hızlı tespit edilmesi ve doğru süreç yönetimi afet olaylarının olumsuz etkilerinin azaltılmasını sağlayacaktır. Bu bağlamda çalışmanın afet ve kriz yönetimi konusunda geliştirilecek politikalara katkı sunması beklenmektedir.

Anahtar Kelimeler: Afet, Kriz, Afet Yönetimi, Kriz Yönetimi, Şanlıurfa.

Jel Kodları: Q54, O18.

\footnotetext{
${ }^{1}$ Dr., Harran Üniversitesi, İIBF, Kamu Yönetimi, e-posta: farukbilbay@gmail.com ORCID: 0000-0002-96345841.

2 Dr. Öğrencisi, Harran Üniversitesi, İ̈BF, Kamu Yönetimi, e-posta: gulben_celik63@hotmail.com ORCID: 0000-0002-8840-3175.
}

\section{Atıf/Citation}

Bilbay, Ö. F., \& Çelik Bozkaya, G. (2021). Afet ve kriz yönetiminin Şanlıurfa ili açısından incelenmesi. Dicle Üniversitesi İktisadi ve İdari Bilimler Fakültesi Dergisi, 11(22), 594-612. 


\title{
EXAMINATION OF DISASTER AND CRISIS MANAGEMENT IN ŞANLIURFA PROVINCE
}

\begin{abstract}
Today, disaster events due to natural and human factors are at the top of the world's agenda. As a matter of fact, disasters are frequently experienced in our country due to human factors such as geographical location, climate change, epidemic events, environmental problems, unplanned urbanization, lack of control, housing security, and insufficient infrastructure. The type and size of disasters may vary according to factors such as the geographical structure of the region where the disaster occurred, the level of development, and disaster awareness. In this respect, Sanliurfa is one of the provinces that should be examined in terms of its location, socioeconomic structure and climatic conditions. Although Şanliurfa is not located in the earthquake zone, it is affected by earthquakes in the surrounding provinces, increasing flood and overflow events in winter, and extreme drought events in summer. In addition, being among the provinces with the highest number of refugees, it is among the provinces that should be examined in terms of adaptation problems, cultural conflicts and urban security. In Şanlıurfa, before disasters turn into a social and administrative crisis, the rapid detection of problems and the right process management will reduce the negative effects of disaster events. In this context, it is expected that the study will contribute to the policies to be developed on disaster and crisis management.
\end{abstract}

Keywords: Disaster, Crisis, Disaster Management, Crisis Management, Şanlıurfa.

Jel Codes: Q54, O18.

\section{GİRİş}

Afetler var olduğu günden beri insanoğlunu siyasal, sosyal, ekonomik ve kültürel açllardan etkilemiştir. Doğal ve beşeri faktörlere bağlı gerçekleşen afetlerle karşılaşan insanlar edindikleri tecrübelerle bu durumla mücadele etmeye çalışmış bu konuda önlemler almak için uğraşmıştır. Fakat günümüzde afet olaylarının sayısının artması ve etki alanları genişlemesi yeni politikaların geliştirilmesini ve önleyici tedbirlerin attırılmasını zorunlu hale getirmiştir. Öyle ki, iklim değişikliği nedeniyle sel, taşkın, fırtına gibi doğal afet olayları daha sık yaşanmaktadır (UNDDR, 2019). Küreselleşmenin de etkisiyle covid-19 gibi benzeri salgınlar daha hızlı yayılabilmektedir (Arslan ve Karagül, 2020: 2). Diğer bir ifadeyle afetler artık daha sık yaşanmakta, insanları ve diğer canlıları daha fazla etkilemektedir. Hükümetler, doğal ve beşeri faktörlere bağlı yaşanan afet olaylarını önlemek veya etki alanını daraltmak amacıyla, yerel, ulusal ve uluslararası boyutlarda çözüm arayışına girmiştir. Bu durum afet yönetimini akademik anlamda en fazla tartışılan konulardan biri haline getirmiştir. Günümüzde afeti meydana getiren faktörlerin tespit edilmesi ve çözümüne yönelik geliştirilecek erken önlem niteliğindeki faaliyetler, afetlerin etkilerinin ve boyutunun azaltılması açısından önemlidir.

Doğal afetler, yerel yönetim birimlerinde sistemden veya alt yap1 hizmetleri yetersizliklerinden kaynaklı olarak çocuk, yaşlı, engelli gibi dezavantajlı grupların olumsuz yönde daha fazla etkilenmesine neden olmaktadır. Bu durum sosyal belediyecilik sorunlarını da gündeme getirmektedir (Çelik, 2014, s.7). Afetlerin günlük yaşamı etkilediği alanların 
başında ise kentler gelmektedir. Çünkü günümüzde artık dünya nüfusunun büyük çoğunluğu kentlerde yaşamaktadır (Satterthwaite, 2020). Türkiye için de benzer durum söz konusudur. 2020 y1lında Türkiye'nin kentsel nüfus oranı \% 64,1 olurken, bu nüfusun \%93'ü il ve ilçe belediyelerinde ikamet etmektedir (TUİK, 2021). Bu bağlamda Türkiye'deki büyükşehirlerde afet olaylarının daha az etki bırakmasını sağlayacak mekanizmaların oluşturulması kent güvenliği açısından da önemli bir yere sahiptir. Şanlıurfa bulunduğu coğrafi konum itibariyle iklim değişikliği ve kuraklık olaylarından en fazla etkilenebilecek bölgede yer almaktadır. Son dönemlerde deprem, sel, taşkın, kaya düşmesi gibi doğal afetler daha sık yaşanmaya başlanmıştır. Ayrıca, 2011 yılında yaşanan Suriye krizi nedeniyle Türkiye’ye yoğun kitlesel bir göç yaşanmış ve bu süreçte Şanlıurfa en fazla sığınmacının yaşadığı kentler arasında ilk sıralarda yer almıştır. Doğal afetlerin yanı sıra yoğun kitlesel göç, kentte sosyal ve ekonomik değişimler, güvenlik riskleri, artan konut talebi, alt yapı yetersizlikleri, mekânsal ayrışma gibi gelişmelere neden olmuştur. Şanlıurfa'da kitlesel göçün, bir krize dönüşmeden sağl1klı bir şekilde yönetilmesi ve olası risklerin tespit edilerek önleyici faaliyetlerde bulunulması etkin bir afet yönetimi için önem arz etmektedir. Şanlıurfa'nın afet ve kriz yönetimini incelemeyi amaçladığımız bu çalışma dört ana bölümden oluşmaktadır. Birinci bölümde, afet ve krizi yönetimine ilişkin kavramlar açıklanmıştır. İkinci bölümde Türkiye'de afet yönetiminin tarihsel gelişimi, afet yönetiminden sorumlu yönetimler ve yasal süreç anlatılmıştır. Üçüncü bölümde, Şanlıurfa'da doğal ve beşeri faktörlere bağlı yaşanmış afet olayları ve nedenlerine yer verilmiş, gelecekte olabilecek afet olayları ve boyutları risk haritaları yardımıyla belirtilmeye çalışılmıştır. Sonuç ve öneriler kısmında ise araştırma kapsamında elde edilen bulgular analiz edilerek, Şanlıurfa'da etkin bir afet ve kriz yönetiminin gelişimine katkı sunacak politika önerilerine yer verilmiştir. Çalışmada veri toplama tekniği olarak belgesel kaynak derlemesi yöntemi kullanılmıştır. Afet ve kriz yönetimine ilişkin kitap, makale, dergi, gazete, haber bülteni gibi yazılı ve görsel materyaller incelenmiş elde edilen bilgiler yorumlanarak çalışmaya aktarılmıştır. Çalışmanın, afet ve kriz yönetimini Şanlıurfa özelinde irdelemesi bakımından önem arz ettiği düşünülmektedir. Çalışmanın Şanlıurfa afet ve kriz yönetimine ilişkin eksiklikleri tespit etmesi ve politika önerileri geliştirmesi bakımından yerel yönetim birimlerine katkı sunması beklenmektedir.

\section{AFET VE KRİZ YÖNETIMINE İLIŞKINN KAVRAMLAR}

Genel olarak afet kavramı, literatüre bakıldığında farklı tanım ve boyutlarda ele alınarak açıklanmaktadır. Arapça kökenli olan Afet kavramı 'büyük felaket, bela, yıkım anlamında kullanılmaktadır (Yavuz, 2014, s. 24). Sözcük anlamı ise toplumu kitlesel olarak etkileyen 
fiziksel ve sosyoekonomik kayıplara neden olan, olağan yaşamsal aktiviteleri bozan ya da aksamalara yol açan ve toplumsal kesimi kontrol altına alma, dayanma gücünün yetemediği tabiat olaylarına, teknolojik ya da kişilerden kaynaklanan olaylara afet denilmektedir. (AFAD, 2014, s. 216). Farklı bir tanımda ise afet, dünyada doğal veya beşeri faktörlere bağlı olarak meydana gelebilen, çok sayıda insanın ve canlının ölmesine ya da yaralanmasına neden olan, çevreye zarar veren, ulaşım, alt ve üst yapının bozulmasına neden olabilecek yıkımlar olarak tanımlanmaktadır (Yaman ve Düger, 2017, s. 3). Afet yönetimi kavramına değinilecek olunursa; afetlerin önlemesi ve zararların azaltılması amacıyla, ihtiyatlı olma, ortaya çıkan durumla mücadele ve baş edebilme gibi yapılması gerekenlerin, ihtiyaçların belirlenmesi için devletin kurumları ve toplum kuruluşlarıyla, mevcut olanaklarının bu çerçeve doğrultusunda ortaya konmasını lüzumlu kılan çok boyutlu bir yönetim biçimidir (Ergünay, 2005, s. 10). Farklı bir tanımda afet yönetimi merkezinde kamu yönetiminin olduğu, insanların güvenli ve sağlıklı bir çevrede yaşamasını engelleyen riskli alanların tespit edilmesi, insan yaşamını tehlikeye sokabilecek teknik, beşeri, doğal ve politik koşulların denetlenmesi, rasyonel kararların alınabileceği yöntemlerin oluşturulması, afet ile ilgili politik süreçlere karar alıcıların dahil edilmesi, afetle ilgili farkındalık oluşturulması ve kültürel yönde benimsetilmesi olmak üzere yönetimsel olarak planlamadan denetime kadar tüm süreçleri kapsayan disiplinler arası bir çalışmadır (Toprak Karaman, 2017, s. 3). Afet yönetimi sadece idari, hukuksal veya siyasal değil aynı zamanda sosyal ve psikolojik boyutunu da kapsamaktadır (Yaman ve Düger, 2017, s. 7). Bu yönüyle afet yönetimi, yerel yönetimlerin, özel ve kamu kurumlarının, sivil toplum kuruluşlarının, toplumun yer edindiği çok aktörlü bir yönetişim sürecidir (Bulut ve Kara, 2016, s. 1046). Özetle afet yönetimi, tehlike ve krizlerin her aşamasında koordineli ekip çalışmasının bulunduğu disiplinler arası yönetim çalışmasıdır.

Kriz, Türk dil kurumuna göre bir ülkenin kendi içinde veya ülkeler arasında görülen bunalım, buhran, güç dönemlerini ifade etmek için kullanılmaktadır (TDK, 2011, s. 1513). Kriz önceden öngörülemeyen, beklenmeyen ve örgütün hızlı karar vermesini gerektirecek durumlarda örgütün uyum ve önleme mekanizmalarını yetersiz hale getirerek mevcut durumun tehdit edilmesine neden olan gerilim durumudur (Dinçer, 2013, s. 407). Yönetim bilimi açısından kriz, "bir kuruluşun üst düzey hedeflerini tehdit eden, kuruluşun varlı̆̆ını tehlikeye sokan ve kuruluşun hızla tepki göstermesinin zorunlu olduğu özel durumlardır." biçiminde tanımlanabilir (Okay ve Okay, 2002, s. 418). Deprem şeklindeki felaketler neticesinde yaşanan olaylar örgütlere dışarıdan baskı oluşturması yönüyle kriz durumu olma niteliğindedir. Bu doğrultuda krizi, doğal afetler, salgın ve hastalıklar, büyük yangınlar, hava 
kirliliği, radyasyon ve kimyasal madde yayılımlarını, ekonomik bunalımları, ani kitlesel nüfus olaylarını veya birlikte oluşturdukları durumu tanımlamak için kullanılabiliriz (Övgün ve Gül, 2019, s. 175).

Kriz yönetimi kavramı ise, kriz şeklinde nitelendirilebilecek olayların meydana gelmeden önce ya da o anda alınacak önlemleri belirleme, kriz sürecinde ve sonrasında ise oluşabilecek zararları minimum düzeyde tutma ayrıca örgütün yeniden yapılanması için gerekli hazırlıkların yapılması ve faaliyetlerin kontrol edilmesini üstlenen yönetim şekli olarak tanımlanabilir. $\mathrm{Bu}$ açıdan kriz yönetiminin öncelikli görevi, örgütün varlığını tehdit edebilecek konuları öngörüp gerekli önlemlerin alınmasına rağmen gerçekleşen krizlerin etkilerinin en az düzeyde gerçekleşmesini sağlamaktır (Büyükkaracığan, 2016, s. 201). Farklı bir tanımda da kriz yönetimi, rutin işleyişi bozacak şekilde aniden gelişen, stres, bunalım, gerilim, risk ve çatışmaların artmasına bağlı olarak yöneticilerin karar verme ve uygulama sürecinde zorlandığı konuların en sağlıklı şekilde idare edilmesi için geliştirilmiş bir yönetim süreci olarak ifade edilmiştir (Tekin, 2015, s. 123).

Afetler, krizleri meydana getiren temel unsurlardandır. Bu çerçevede afet sebebiyle vuku bulan durumlarda meydana gelen krizler önceden tahmin edilememekte ayrıca erken uyarı sistemleri de yeteri kadar önleyici olamamaktadır. Bu açıdan afet durumlarında oluşabilecek öngörülemeyen durumlar engellenemediği için bu süreçte yaşanan krizler diğer kriz türlerinden farklı olarak ayrılmaktadır (Tutar, 2004, s. 28). Her afet aynı zamanda bir kriz kaynağı mıdır? Bu sorunun cevabına kesinlikle evet diyebilmek mümkün değildir. Çünkü afetlerin büyüklük ya da etkisini belirleyen çeşitli unsurlar mevcuttur. Ayrıca meydana gelen afetin kriz kaynaklı olup olmadığı ancak bu unsurların değerlendirilmesiyle görülecektir. $\mathrm{Bu}$ bağlamda bir afetin kriz, olarak değerlendirilebilmesi için yerleşim alanlarında meydana gelmeli ve can, mal kaybına ya da en azından birine sebep olmalıdır (Yahmed, 1994, s. 27). Doğal afetlerden ötürü oluşan kriz durumlarındaysa insanların sağlık ve güvenlikle ilgili sorunları kriz yönetim planlamasında ilk sırada yer almaktadır. Sonra da çevrenin ve menkul ve gayrimenkul malların muhafazası ve kurtarılması yer almaktadır. Öte yandan, tabii afetlerden dolayı oluşan kriz hallerinde şahsi davranışlar oluşmaktadır. Fertler, kriz yönetimini yapamama durumlarında, meydana gelen afeti ferdi gayretlerle kurtarma ve korumaya çabalamaktadır bundan dolayı, tabii afetler, ferdi gayretlerin oldukça ötesinde, etkili bir takım çalışmasını icap ettiren kriz halleridir. Takımdaki her bir ferdin şahsi mesuliyetinin farkında olması kriz yönetiminin vazgeçilmez bir unsurudur (Yavaş, 2001, s. 55). Ayrıca kriz yönetiminin tüm aşamalarında koordineli bir şekilde ekip çalışmasının 
oluşturulması, iletişim içinde olan herkesle rahat anlaşılabilmesi ve krize neden olan olayların daha iyi anlatılabilmesi, etkili çözüm önerilerinin oluşturulabilmesi bakımından önem teşkil etmektedir.

\section{TÜRKIYE'DE AFET YÖNETIMININ GELIŞíMI}

Türkiye'de afet yönetiminin gelişimini cumhuriyet öncesi ve cumhuriyet sonrası olarak iki bölümde incelemek mümkündür. Cumhuriyet öncesi dönemde afet yönetimine ilişkin kapsamlı bir yasal düzenleme olmamakla birlikte ilk düzenleme 13 binden fazla insanın hayatını kaybetmesine, İstanbul'da birçok binanın yıkılmasına neden olan 14 Eylül 1509 tarihli deprem sonrasında Osmanlı Padişahı olan II. Beyazıt tarafından oluşturulan bir fermandır. Bu ferman ile depremde zarar gören ailelere hane başına 20 bin altın maddi yardım yapılması emredilmiştir. (TBMM, 1999, s. 12). Cumhuriyet sonrası dönemde ise 1939 Erzincan Depremi ile başlayan Niksar-Erbaa, Adapazarı-Hendek, Tosya-Lâdik ve Bolu Gerede depremleri sonrasında 1944 yılında "623 sayılı Yer Sarsintılarından Evvel ve Sonra Alınacak Tedbirler Hakkında Kanun” yayımlanmış. 1959 yılında çıkarılan “7269 sayılı Umumi Hayata Müessir Afetler Dolayısıla Alınacak Tedbirlerle Yapılacak Yardımlara Dair Kanun” yürürlüğe girmiştir. Afet bölgesine devletin tüm olanaklarının en hızlı biçimde ulaşmasını sağlamak ve afetzedelere ilk müdahalelerin yapılması amacıyla 1988 yılında Afetlere İlişkin Acil Yardım Teşkilatı ve Planlama Esaslarına Dair Yönetmelik yürürlüğe girmiştir (AFAD, 2012, 19). Türkiye'de afet yönetimi anlayışı ve teşkilatlanmasında en önemli dönüşüm sürecini ise, 17 Ağustos 1999 Marmara Depreminin sonrasında gerçekleştirmiştir. Bu süreç doğrultusunda Türkiye'de afet yönetimi sisteminde 2009 yılı süresince çok başlı bir yönetim ve uygulama çeşitliliğinin yaşandığı söylenebilir. AFAD’ın kuruluşu afet yönetimi sistemimizde yaşanan çok başlılığı ortadan kaldırmak maksadıyla 29.05.2009 tarihinde 5902 sayılı "Afet ve Acil Durum Yönetimi Başkanlığının Teşkilat ve Görevleri Hakkındaki Kanun" yürürlüğe girmiştir (Papuç, 2010, 32). AFAD’ın kurulmasıyla birlikte daha önce afet yönetim sürecini işleten Başbakanlığa bağl1 Türkiye Acil Durum Yönetimi Genel Müdürlüğü, Bayındırlık ve İskân Bakanlığına bağlı Afet İşleri Genel Müdürlüğü ve İçişleri Bakanlığına bağlı Sivil Savunma Genel Müdürlüğü kaldırılarak bu kurumların tüm görev, yetki ve sorumlulukları AFAD’a aktarılmıştır. Bu bağlamda AFAD’a bağlı afet ve acil durum koordinatörlüğü ve sivil savunma koordinatörlüğüyle ilgili tüm işlerden sorumlu ve koordinatör birim görevlendirilmesi şeklinde oluşan çok başlılık ortadan kaldırılmıştır (Bulut ve Kara, 2016, s. 1046). 15 Temmuz 2018 yılında ise Cumhurbaşkanlığı Hükümet Sistemi kapsamında yapılan değişiklik ile Afet ve Acil Durum Yönetimi Başkanlığı 
İçişleri Bakanlığına bağlanmıştır. AFAD çalışmalarını 4 No'lu Cumhurbaşkanlığı Kararnamesi ile iç işlerine bağlı olarak yerine getirmektedir.

Afet yönetimine ilişkin mevzuatta yer alan yasal düzenlemeler şöyledir;

5902 sayılı Afet ve Acil Durum Yönetimi Başkanlığının Teşkilat ve Görevleri Hakkında Kanun

$\checkmark 7269$ sayılı Umumi Hayata Müessir Afetler Dolayısıyla Alınacak Tedbirlerle Yapılacak Yardımlara Dair Kanun

4123 sayılı Tabii Afet Nedeniyle Meydana Gelen Hasar ve Tahribata İlişkin Hizmetlerin Yürütülmesine Dair Kanun

7126 sayılı Sivil Savunma Kanunu

6305 sayılı Afet Sigortaları Kanunu

6306 sayılı Afet Riski Altındaki Alanların Dönüştürülmesi Hakkında Kanunlar yer almaktadir (Bulut, vd., 2017, s. 14).

Bakanlıklara Bağlı, İlgili, İlişkili Kurum ve Kuruluşlar İle Diğer Kurum ve Kuruluşların Teşkilatı Hakkında 4 Nolu Cumhurbaşkanlığı Kararnamesi (mevzuat.gov.tr).

\section{4. ŞANLIURFA'DA AFET KRİZ YÖNETIMI}

Bu bölümde Şanlıurfa'da kriz unsuru oluşturabilecek afet olayları ve yaşanan olaylara ilişkin verilere yer verilmiştir. Araştırma alanına ilişkin bilgiler kısmında Şanlıurfa'nın sosyoekonomik durumu açıklanmıştır. Materyal, yöntem ve kapsam kısmında verilerin toplanma ve analiz yöntemi ortaya konulmuştur. Şanlıurfa'da afet ve kriz yönetimi bölümünde, afet ve kriz durumu oluşturabilecek olaylar ve acil önlem alınması gereken konular risk ve kuraklık haritalarıyla belirtilmiştir. Böylelikle Şanlıurfa'da afet ve kriz durumunu meydana getirecek olayların önem ve öncelik sırası belirlenmeye çalışılarak bu konuda politika önerileri geliştirilmesi amaçlanmıştır.

\subsection{Araştırma Alanına İlişkin Bilgiler}

Şanlıurfa, tarih boyunca birçok millete ve medeniyete ev sahipliği yapmış bir ildir. Şehrin sahip olduğu hoşgörü kültürü farklı medeniyet ve milletten insanın bir arada huzur içinde yaşamasına olanak tanımaktadır. Sosyo-ekonomik özellikleriyle de ön plana çıkan Şanlıurfa diğer illere nazaran doğum hızının yüksek olması, tarım alanlarının geniş yer kaplaması, Suriye ile sınır komşusu olması, Türkiye'nin en fazla sı̆̆ınmacı nüfusuna sahip illerinden 
birisi olması bakımından önem ihtiva etmektedir. Şanlıurfa'nın nüfusu 2020 yılı verilerine göre 2 milyon 115 bin 256 kişidir (TÜİK, 2021). Sığınmacı sayısı 425 bin 564 kişi olup toplam nüfusun \%20'sini oluşturmaktadır (www.goc.gov.tr, 2021). Şanlıurfa, Güneydoğu Anadolu Projesi'nin merkezi konumundadır. Bu açıdan oluşabilecek riskler projenin de etkilenmesine neden olacaktır.

\subsection{Materyal, Yöntem ve Kapsam}

Çalışmada verilerin toplanmasında belgesel kaynak derlemesi verilerin analizinde ise betimsel analiz yöntemi kullanılmıştır. Konuyla ilgili kitap, dergi, makale, gazete, yasal belge vb. veriler çalışmanın ana kaynaklarını oluşturmuştur. Çalışma, derinlemesine analiz için Şanlıurfa ili ile sınırlı tutulmuştur.

\section{3. Şanlıurfa'da Afet ve Kriz Yönetimi}

Bu kısımda Şanlıurfa'da deprem, sel ve taşkın, kaya ve çı̆̆ düşmesi, kuraklık gibi doğal afetler ve kitlesel göç, salgın gibi beşeri faktörlere bağlı afet olayları ve kriz yönetimi açısından irdelenmiştir. İlk olarak doğal afet niteliğindeki olayların meydana getirebileceği riskler haritalar yardımıyla ortaya konulmuş daha sonra sığınmacıların meydana getirdiği sosyoekonomik değişimler afet ve kriz yönetimini nasıl etkilediği açıklanmaya çalışılmıştır.

Şanlıurfa'da doğal kaynaklı afetlerin türlerine bakıldığında deprem, sel, taşkın, kuraklık, kaya düşmesi gibi olayların ön plana çıkmaktadır. İlk olarak Şanlıurfa'nın depremselliğine afet riskleri yönünden bakılacak olursa; Şanlıurfa ilinin depremselliği afet riskleri yönünden doğa kaynaklı; diri fay sistemi üç ana sınıf altında toplanmaktadır. Bunlar bölgede batıdan doğuya doğru uzanan Karacadağ açılma çatlağı, Urfa ve Besni yöresi diri faylarıdır. Türkiye'nin tektonik çatısı içerisinde en duyarlı bölgesinde yer alan bu faylar Urfa yöresinde, tarihsel dönemlerde yıkıcı depremlere neden olmuştur. Öyle ki günümüzde tarih ve turizm açısından çok önemli olan Harran Şehri'nin yıkıcı etkileye sahip bir deprem nedeniyle yıkılmış olabileceği düşünülmektedir. Doğu Anadolu Fay sistemiyle yakın geometrik ilişkileri olan Besni yöresine bağlı, Suvarl1-Tut arasında yer alan faylar, morfolojik olarak belirgin düzeydedir (Şaroğlu vd., 1987, s. 394). Bu bağlamda her ne kadar Şanlıurfa birinci derece deprem bölgesinde yer almasa da birinci derece deprem bölgesine yakın illere komşu olması nedeniyle bu illerde yaşanan depremlerin Şanlıurfa'da da hissedilmesine neden olmaktadır.

Şanlıurfa İl Afet ve Acil Durum Müdürlüğünden edinilen bilgiye göre; Şanlıurfa İl genelinde 8 adet AFAD başkanlığına ait deprem istasyonu 1 adette kandilli rasathanesine bağlı olmak üzere toplamda 9 adet deprem istasyonu bulunmaktadır. Bu istasyonlar vasıtasıyla depremler 
anlık olarak tespit edilebilmektedir. Aşağıda Şanlıurfa'nın depremsellik riskini gösteren harita verilmiştir.

\section{Şekil 1. Şanlıurfa'nın Depremselliği Fay Hatları (KAF, DAF)}

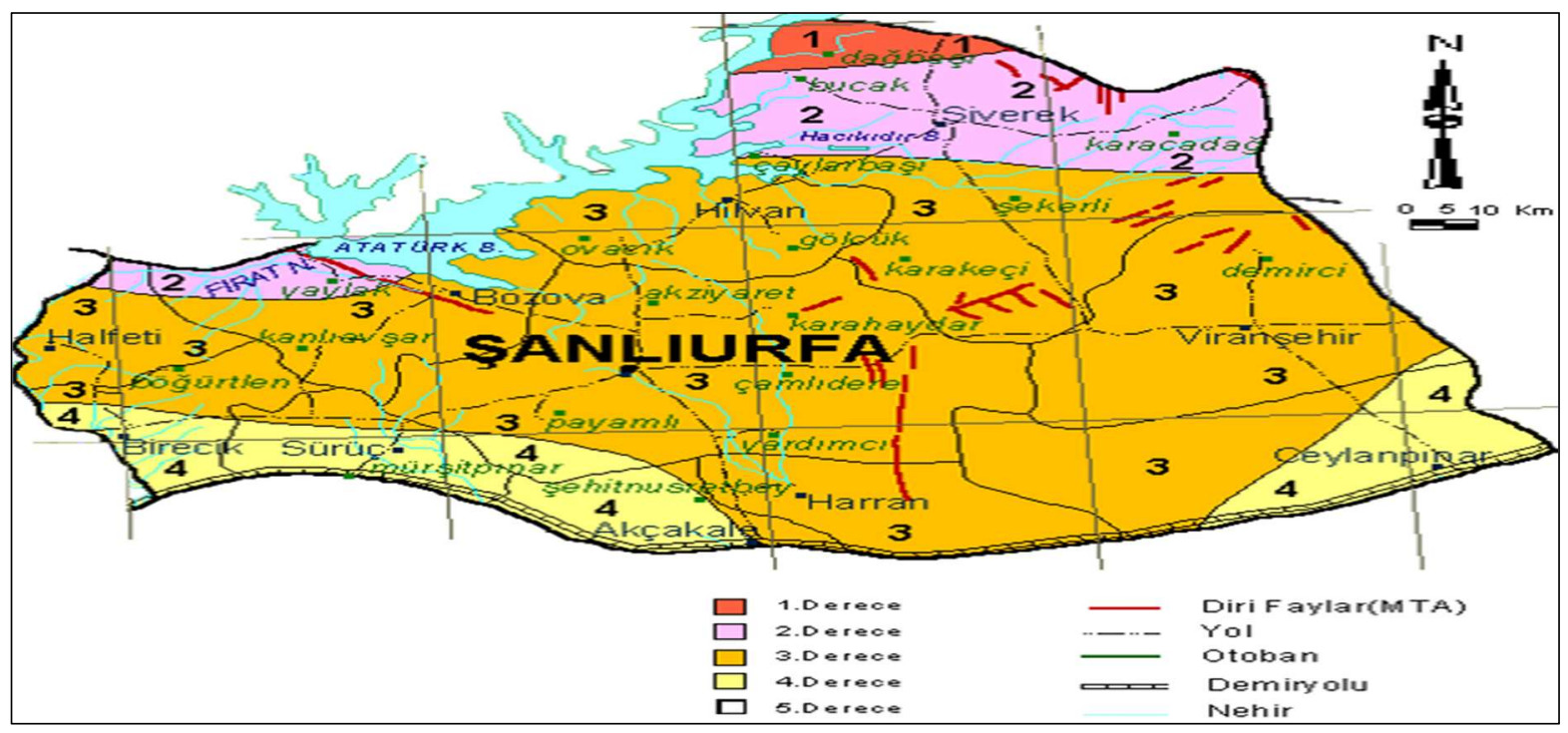

Kaynak: Şanlıurfa İl Afet ve Acil Durum Müdürlüğü, 2020

Deprem risk haritası incelendiğinde risklerin kuzeyde daha yüksek olduğunu göstermektedir. Atatürk Barajı'nın ikinci derece deprem bölgesinde yer alması olası depremlerden etkilenme ihtimallerini güçlendirmektedir. Şanlıurfa'nın deprem bölgesinde olmamasına rağmen Adıyaman, Bingöl, Malatya, Elazı̆̆ gibi çevre illerde meydana gelen depremler halkta tedirginlik oluşturmaktadır. Deprem anında halk panikle sokağa çıkmakta ve kontrolsüz bir şekilde sağa sola gitmektedirler (www.urfafanatik.com). Boğaziçi Üniversitesi Kandilli Rasathanesi ve Deprem Araştırma Enstitüsü (KRDAE) verilerine göre son yıllarda Şanlıurfa'da deprem sayısı giderek artmaktadır (KRDAE, 2021). Ayrıca Şanlıurfa'nın jeolojik toprak yapısının zayıf olması, sırın gibi yeni yerleşim yerlerinin kil benzeri zemine sahip olması, binaların çoğunluğunun eski ve depreme dayanıklı olmayışı da Şanlıurfa'da olası depremlerin yıkıcı etkisini arttırmaktadır (Gümüşçü vd., 2004: 41-52). Depremin meydana geldiği alanlarda deprem risk derecesi kadar yerleşim yerlerinin planlı olması ve binaların depreme dayanıklı şekilde inşa edilmesi de depremin yıkıcı etkilerinin azaltılması bakımından önem arz etmektedir. Halkın deprem olduğunda panikle sokaklara çıkması ve kontrolsüz şekilde sağa sola gitmesi deprem anında yetkili birimlerin olaylara müdahale etmesini güçleştirmektedir. Bu açıdan kentlin belirli noktalarında oluşturulacak kriz masası, olası afet anında sürecin sağlıklı yönetimine katkı sunacaktır.

Aşağıda Şanlıurfa'da meydana gelebilecek diğer bir afet türü olan sel ve su baskınları şekil de harita yardımıyla gösterilmeye çalışılmıştır. 
Şekil 1. Şanlıurfa'da Yakın Bir Zamanda Meydana Gelen Sel ve Su Baskınları

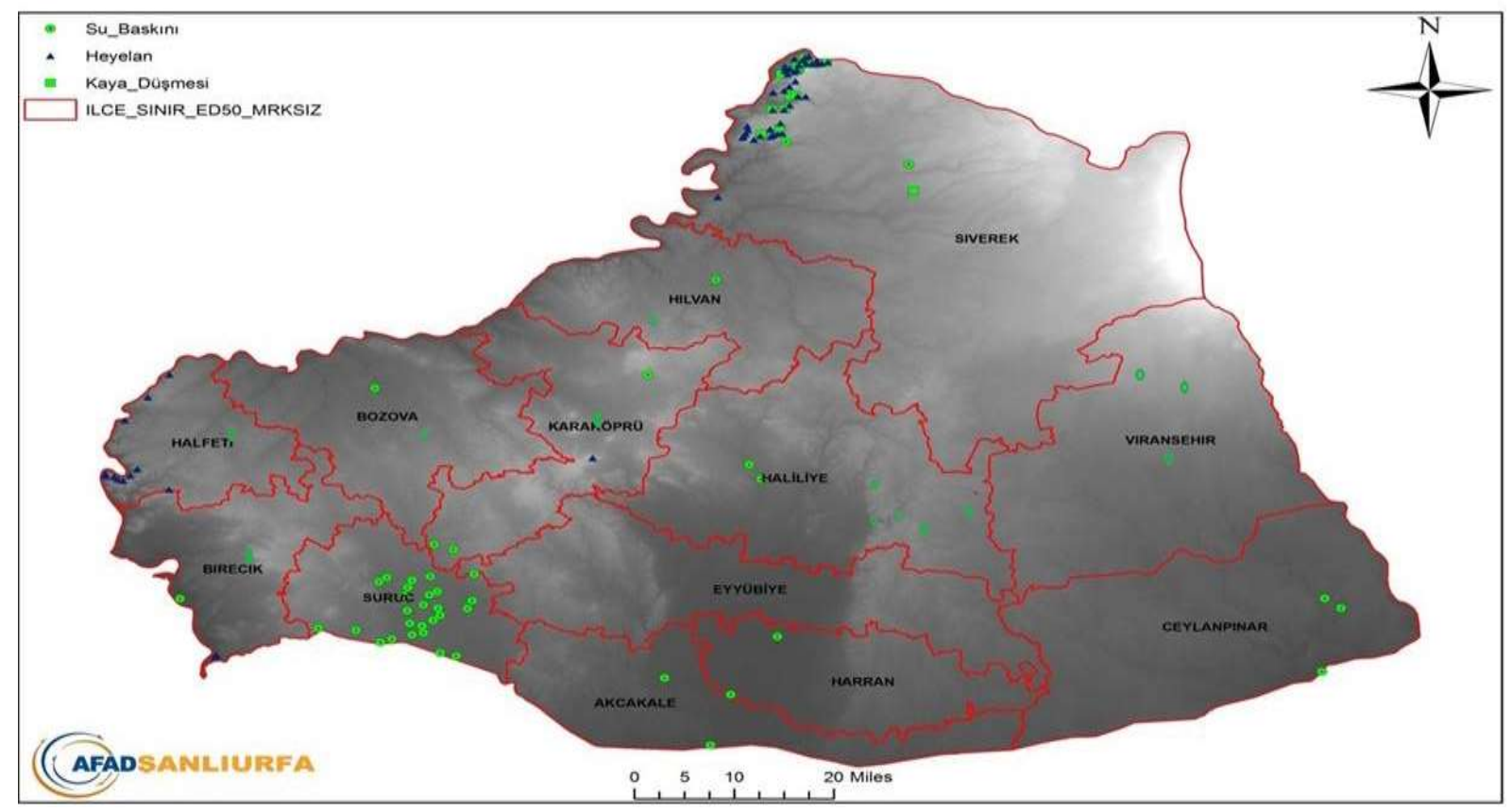

Kaynak: Şanlıurfa İl Afet ve Acil Durum Müdürlüğü, 2020

Şekil 2 ‘de görüldüğü ve AFAD’dan edinilen bilgi üzerine Güney kısım ve ağırlıklı olmak üzere Suruç Hilvan, Siverek güzergâhlarında da kısmi yağış oluşmuştur (AFAD, 2020). Şanlıurfa'da sel ve taşkın olaylarının artmasında klimatik ve jeomorfolojik özelliklerin yanı sıra yerleşim yeri veya tarımsal amaçlı dere yataklarının doldurulmuş olması, yol ve köprü menfezlerinin tıkalı olması gibi beşeri faktörler etkili olmuştur. Daha önceki yıllarda meydana gelen sel ve taşkın olaylarında can ve mal kayıpları yaşanmıştır (Şahinalp,2007:90). Ayrıca bilinç eksikliği, hatalı planlama, yetersiz mühendislik uygulamaları, erken uyarı sistemlerinin bulunmayışı/yetersizliği, kurumlar arası iletişim eksikliği, eğitimsizlik, veri güncellemeleri, taşkın koruma yapılarının temizliği unsurlar Şanlıurfa'da afet olaylarının etkisini arttıran diğer unsurlar olmaktadır (Sepetçioğlu, 2013, 35-37). Şanlıurfa'da afet olaylarının etkisini azaltılması için ilçe ve kırsal alanlarda görülen olaylara ilk müdahaleler halka en yakın yerel yönetim birimlerince gerçekleştirilmesi ve bu noktalarda AFAD’a destek olunması açısından kriz masasının oluşturulması önem arz etmektedir.

Yine İlin Heyelan durumu ise aşağıdaki risk haritasıyla açıklanmaya çalışılmıştır. 
Şekil 2. Şanlıurfa'nın Heyelan Durumu

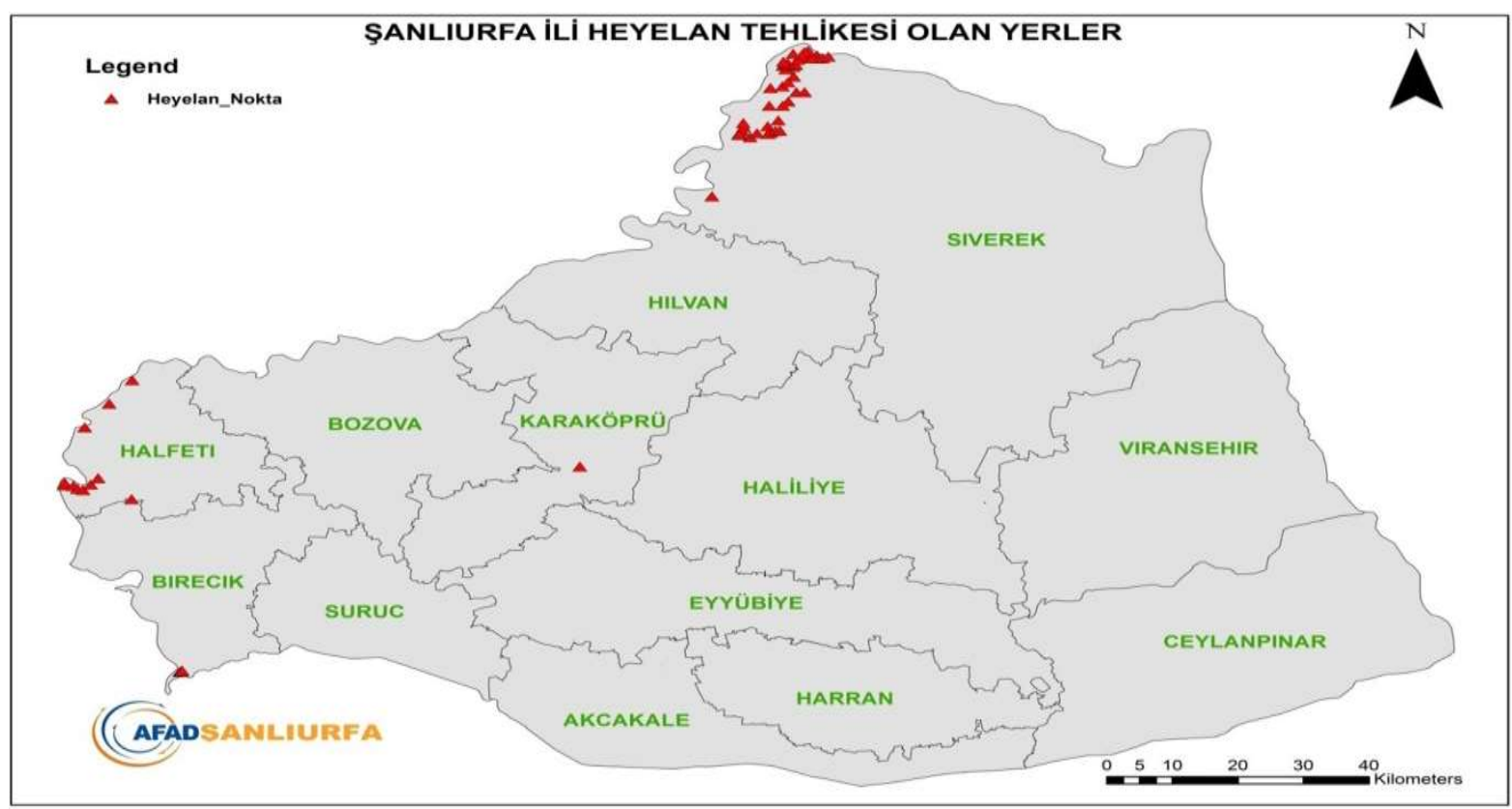

Kaynak: Şanlıurfa İl Afet ve Acil Durum Müdürlüğü, 2020

Şekil 3'de ise heyelan görülme durumu çok azda olsa Siverek, Halfeti ve Birecik gibi minimal düzeyde görülmektedir. Şanlıurfa'da kaya düşmesi durumu ise aşağıda şekil 4'de belirtilmiştir.

Şekil 3. Şanlıurfa'nın Kaya Düşmesi Durumu

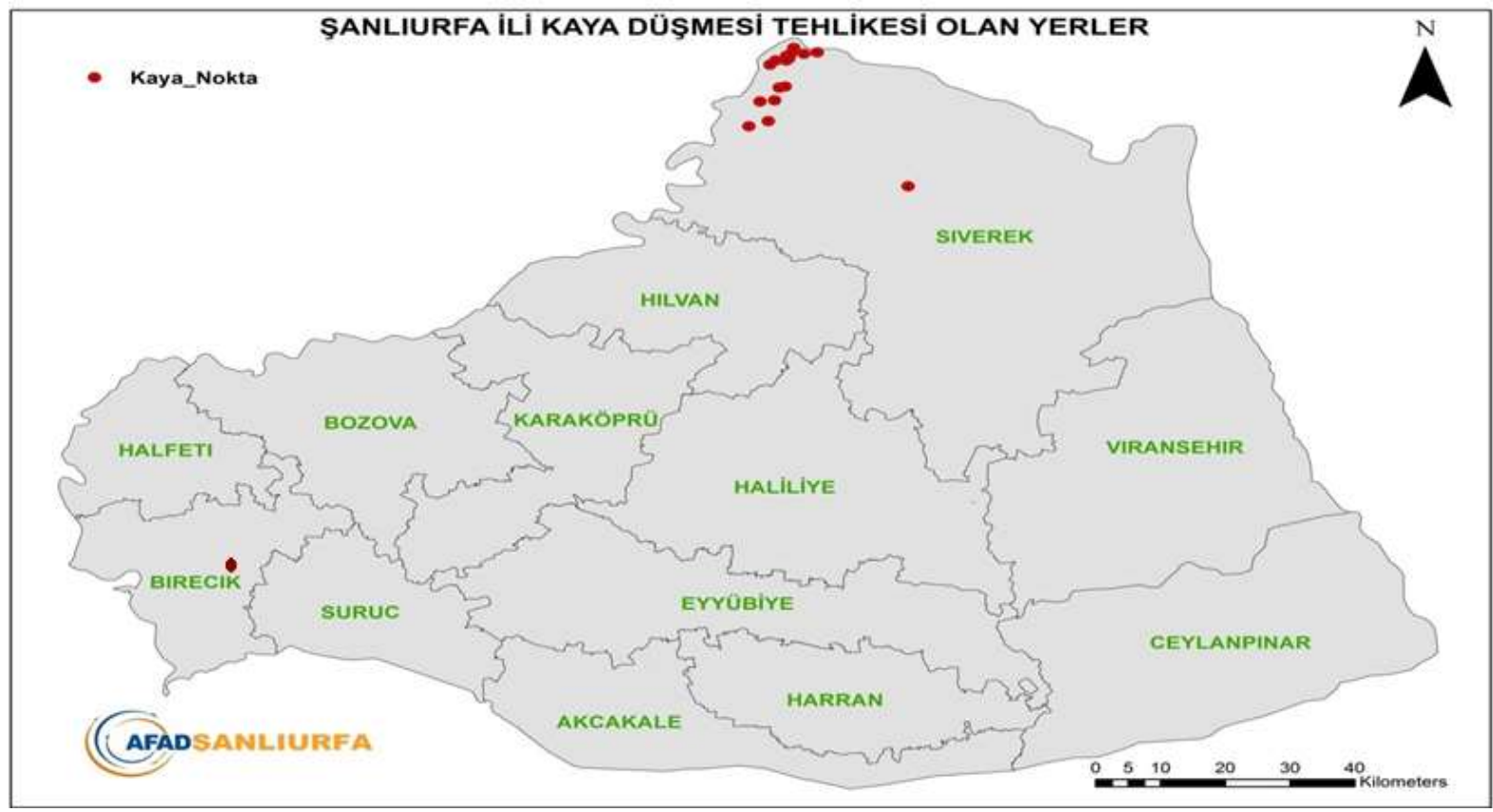

Kaynak: Şanlıurfa İl Afet ve Acil Durum Müdürlüğü, 2020 
Şekil 4'e göre tehlikeli kısımlar Birecik ve Siverek alanlarında yer almaktadır. Nitekim Birecik ilçesinde meydana gelen kaya düşmesi nedeniyle maddi hasar oluşmuş ve Birecik Halfeti yolu uzun süre trafiğge kapanmıştır. Bu süre zarfında ilçeye çevre illerden meyve, sebze girişi yapılamamıştır. Kayaların risk unsuru teşkil etmesine rağmen tedbir alınmaması ve uzun süreçli çözüm üretilememesi nedeniyle ikinci ve üçüncü kez kaya düşmeleri meydana gelmiştir (Darıc1, 2021). Henüz doğal bir afet yaşanmadan meydana gelen kaya düşmeleri göz önüne alındığında olası deprem anında kaya düşmesi olayının etki ve boyutunun daha fazla olacağı kaçınılmaz görülmektedir.

.Şekil 4. Şanlıurfa'nın Çı̆̆ Durumu

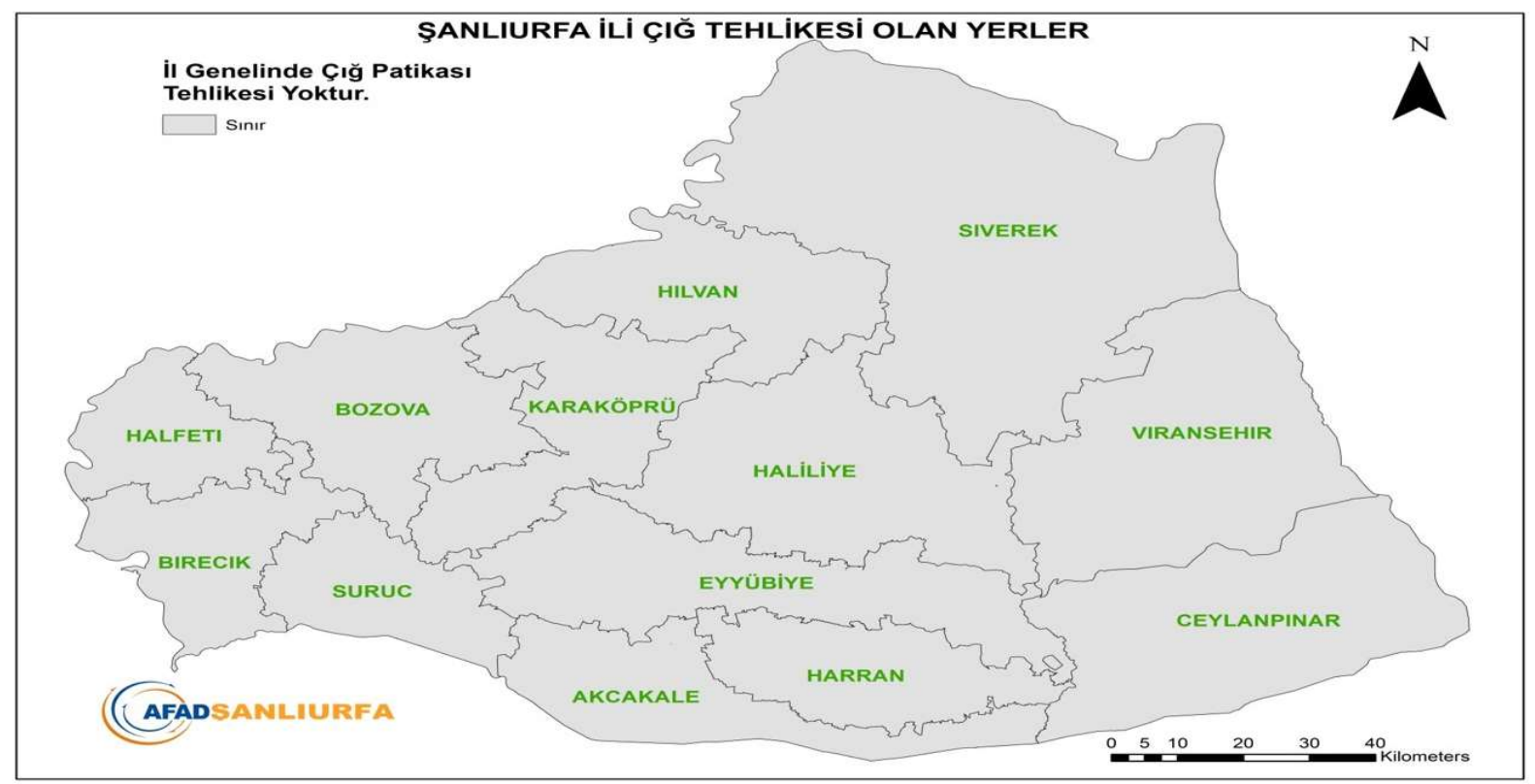

Kaynak: Şanlıurfa İl Afet ve Acil Durum Müdürlüğü, 2020

Şanlıurfa ilinde Çı̆̆ görülüp görülmemesi hususunda şekil 5'de de görüldüğü üzere Şanlıurfa il genelinde Çı̆̆ tehlikesi bulunmamaktadır.

Şanlıurfa bulunduğu coğrafi konum itibariyle kurak bir bölgede yer almaktadır. Endüstrinin çok fazla gelişmemiş olması nedeniyle kırsal kesimde halkın çoğu geçimini çiftçilik ile sağlamaktadır. Ayrıca üretim alanı kısıtlı olan Antep Fıstığının yanı sıra olası kuraklıklardan pamuk arpa, buğday, mısır gibi bölgenin önde gelen tarım ürünleri de ciddi şekilde etkilenmektedir. Şanlıurfa'nın bazı bölgelerinde kış aylarında meydana gelen sel felaketleri ve yaz aylarında yaşanan kuraklık nedeniyle Şanlıurfa'nın afet bölgesinde yer alan iller arasında yer alması talep edilmektedir (Kamer, 2021). Nitekim kurak dönemler son yıllara göre artmaktadır. $\mathrm{Bu}$ durum kuraklıkla ilgili çok yönlü eylem planlarının gerekliliğini ortaya koymaktadır. Şanlıurfa'nın iklimi, hidrografyası, hidroklimatolojisi iyi analiz edilerek, bilinen 
tüm yönleriyle sürdürülebilir ve uygulanabilir çalışmaların planlanması büyük önem arz etmektedir (İrcan ve Duman, 2021: 16).

Nitekim erken önlem alınmaması halinde kuraklık olaylarının tekrar etmesi ve bu durumdan öncelikli olarak su kaynaklarının, tarımsal üretimin zarar görmesi kaçınılmaz görülmektedir. Halkın çoğunluğunun çiftçilikle uğraştığı ve su kaynaklarının yetersizliği göz önüne alındığında sosyoekonomik yapının olumsuz etkileneceği söylenebilir.

Aşağıdaki şekil 6'da Şanlıurfa'nın kuraklık risk haritasına yer verilmiştir.

Şekil 5. Şanlıurfa Meteorolojik 6 Aylık KuraklıkHaritası (Ocak-Haziran 2021)

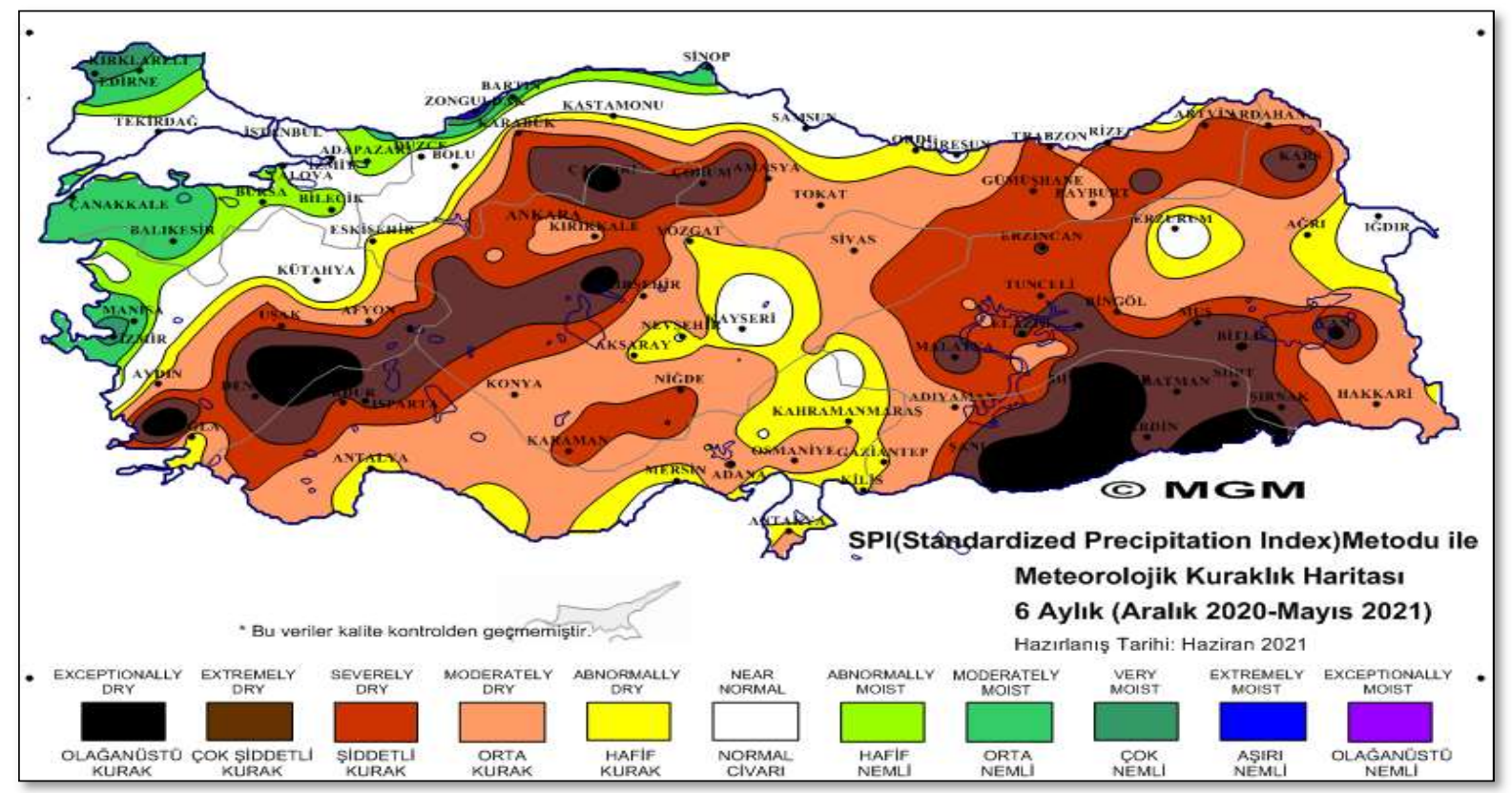

Kaynak: https://www.mgm.gov.tr/veridegerlendirme/kuraklik-analizi.aspx

Kitlesel göç hareketleri sonucu afet olayları ve akabinde oluşabilecek kriz durumu bağlamındaysa 2011 yılında Suriye'de ortaya çıkan çatışma ortamından Türkiye'ye sığınan Suriyelilerin Türkiye'nin kitlesel göç anlamında yaşadığı en büyük krizlerden birini oluşturduğunu söylemek mümkündür. TÜİK'den edinilen son verilere göre sadece 2018-2019 yılları arasında Türkiye'ye gelen Suriyeli sayısı 43190'dır (TUİK, 2020). Şanlıurfa ili bazındaysa 2016 yılında il göç idaresi müdürlüğünden edinilen verilere göre şehir merkezinde 401.050 kayıtlı sığınmacı bulunmaktadır. Bununla beraber şehir kayıtlı olmayan sığınmacıları da barındırmaktadır (Çelik ve Yıldırım, 2016, s. 241). Türkiye genelindeki iller ile kıyaslandığına Şanlıurfa'nın kayıtlı ve kayıtsız olmak üzere yüksek oranda sığınmacıyı barındırdığ 1 görülmektedir. 
Kitlesel göç babında ise Şanlıurfa'da sığınmacıların gıda, barınma, güvenlik, eğitim, sağlık vb. alanlarda sorun yaşamasına neden olmuştur. Bu durumu 2016 yılında Çelik ve Yıldırım'ın Şanlıurfa ilinde yapmış olduğu çalışmada dönemin Şanlıurfa Büyükşehir Belediye Başkanı şu şekilde değinmektedir: Genel olarak karşılaşılan sorunlara bakıldığında sığınmacıların sosyal uyum sürecinde, mekân yetersizliğine sahip olduğunu ve fiziki mekân tedariklerinin kolay olmadığını dile getirmiştir. Ayrıca alt yapı sorunlarının oluştuğunu ve bu durumun içme suları, sosyal alanlar, eğitim alanları, park-bahçe alanlarıyla birlikte esnaf kesime de bir yük teşkil etmekte olduğu belirtilmiştir. Özellikle alt yapı, ulaşım, temizlik gibi sorunlarla da kentte ayrıca bir yükü barındırdığını ifade etmiştir. Yine bu çerçevede büyükşehir belediye başkanı 2015 y1lı itibariyle Şanlıurfa nüfusunun13 ilçeyle beraber 1 Milyon 892.000’e ulaştığını vurgulanmıştır. Hizmetler bağlamında belediyeler olarak kentte mevcut nüfusa göre bir planlama yapılmış fakat kentin bu yoğun nüfusuna 500.000'den fazla sığınmacının da eklenmesiyle birlikte temiz içme ve kullanma suyu sağlanması, alt yapı ve üst yapı gibi hizmetlerin bu durumdan olumsuz etkilendiği belirtilmiştir. Parkların, kentin kapasitesinden fazla nüfusa hizmet etmesinden ötürü daha fazla deforme olduğu, fazla nüfusun trafiğe ekstra yük getirdiği, ayrıca kent merkezinin de daha fazla kirlendiği önemle belirtilmiştir. Şanlıurfa ilinde yoğun oranda oluşan Suriyeli kitlesel göç akını, kentin üzerindeki yükünün büyük oranda arttırdığı vurgulanmıştır. Şanlıurfa ilinde nüfus yoğunluğunun yüksek bir orana ulaştığı, ilerleyen zamanlarda bu yoğunluğun ciddi sorunlara yol açabileceği belirtilmektedir (Çelik ve Yıldırım, 2016: 242-247). Bu sebeple oluşan krizin çatışma ortamına neden olmadan yönetilmesinde AFAD, Şanlıurfa İl Göç İdaresi, sivil toplum kuruluşları ve yerel yönetimlerin katkısının büyük olduğu söylenebilir.

Afetin kriz durumuna neden olmasının başlıca faktörlerinden birisini de afet bilinci ve doğru afet yönetim süreci oluşturmaktadır. Afet konusunda tedbirli olmayan çiftçiler, vatandaşlar ve yerel yönetim birimleri olası afet durumunda ani ve sağlıksız kararlar alabilmektedirler. Kuraklık tehlikesine karşı yanlış ürün seçmek, afet olaylarına rağmen çarpık kentleşmeye devam etmek, afette nasıl davranacağı konusunda bilgilendirme seminerlerine katılmamak afetin şiddetini artıran unsurlar arasında yer almaktadır. Bu bağlamda afet yönetiminde başarı sağlanabilmesi için toplumsal kaynakların etkin bir biçimde geliştirilmesi önem arz etmektedir. $\mathrm{Bu}$ kaynaklarda ise belirtilmek istenen problem çözebilme, inisiyatif oluşturabilme, iletişim kurabilme, ilk yardım, arama-kurtarma, toplumsal açıdan güvenlik ve huzur sağlama gibi gerekli farklı konularda yetişmiş ve bilgi ve teknolojiyle desteklenmiş bireyler yetiştirebilmektir ( Kadığlu, 2008, s. 20). 
Şekil 6. Türkiye Geneli Afet Bilinci Eğitimine Katılım Sayısı Grafiksel Gösterimi

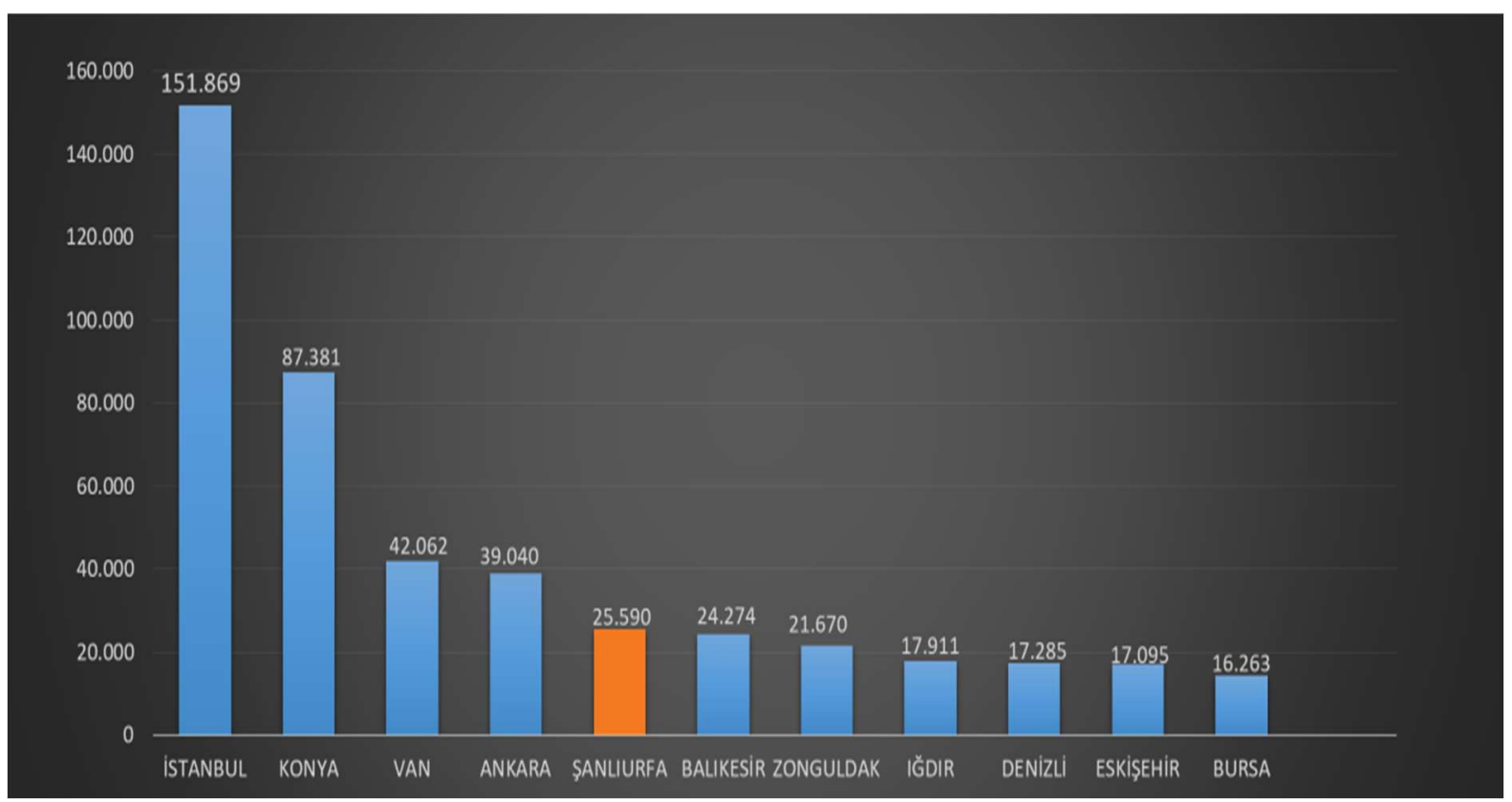

Kaynak: Şanlıurfa İl Afet ve Acil Durum Müdürlüğü, 2020

Şekil 7'ye bakılacak olunursa Türkiye genelinde Şanlıurfa ili Afet eğitim bilincinin \%25'lik kısmındadır. $\mathrm{Bu}$ açıdan afet bilinci kültürünün yaygınlaşması önem arz etmektedir. Şanlıurfa'nın deprem bölgesinde olmaması diğer afet türlerinden etkilenmeyeceği anlamına gelmemektedir. Halkın afetlerin türü, boyu ve alınması gereken tedbirler konusunda bilinçlendirilmesi olası afet olaylarının krize dönüşmeden veya kriz sürecinde afetin sağlıklı yönetimine katkı sağlayacaktır.

\section{SONUÇ VE ÖNERILER}

Literatür taraması neticesinde elde edilen bulgular şöyledir:

- Günümüzde doğal ve beşeri faktörlere bağlı afet olayları artmakta afetlerin etki alanları genişlemektedir.

- Afet yönetiminin bir krize dönüşmemesi için etkin bir yönetimi gerekli k1lmaktadır. Etkin afet yönetimi, kamu kurum ve kuruluşlarının, yerel yönetimlerin, STK'ların, özel sektörün, halkın ayrıca uluslararası kuruluşları da kapsayan birçok yönden dayanışma içinde olduğu bir yapı ile mümkün olabilecektir.

- Ülkemizde her ne kadar etkin bir afet yönetimi için görev ve sorumluluklar tek merkezde toplanarak çok başlılık önlenmeye çalışılmışsa da bu durum yerel yönetimlerin afet konusunda pasif duruma düşmeleri algısını meydana getirmiştir. 
Alan araştırması kapsamında ise şu bulgular tespit edilmiştir:

- Kuraklık, sel ve taşkınlar, kitlesel göç, küresel salgınlar afet konusunda krizi meydana getirebilecek risk potansiyeli yüksek olaylardır.

- Deprem sayısı artmakla birlikte deprem bölgesinde olmamasın verdiği yanıltıcı güvenlik nedeniyle halkın deprem bilinci düşük düzeyde kaldığı söylenebilir.

- Halk afet konusunda hazırlıklı olmaması nedeniyle olası bir deprem anında endişeye kapılabilmektedir.

- Kış aylarında sel ve taşkın, yaz aylarında ise kuraklık olayları ve etkileri artmaktadır.

- Bölge iklim değişikliği ve kuraklık olaylarından ciddi şekilde etkilenmektedir. Şanlıurfa ekonomisinin büyük bir kısmı tarıma dayalı olduğunda kuraklık nedeniyle meydana gelebilecek olumsuzluk sadece Şanlıurfa için değil bölge için gıda krizi sorununu oluşturabilecektir.

- Şanlıurfa, sığınmacı sayısı bakımından Türkiye'nin dördüncü ili konumundadır. Olası kültürel çalışma veya uyum sorunlarından etkilenme düzeyi yüksektir.

Afetin etkilerinin azaltılması ve Şanlıurfa özelinde etkin bir afet yönetimi için şu öneriler geliştirilmiştir:

- Etkin bir afet yönetimi için tüm yerel yönetim birimlerinde koordinasyonu sağlayabilecek daha etkin ve bilinçli kriz masaları oluşturulmalıdır.

- Afet durumunda her kurum kendi görevi alanına girebilecek konularda yetkilendirilmedi tüm görev ve sorumluluk merkezi yönetime bırakılmamalıdır.

- Yerel yönetimlere daha bilinçli düzeyde kriz ve afet durumlarında merkezi yönetim tarafından etkili görev ve yetkiler verilmeli, mali yardımlarla desteklenmeli afet yönetiminde rol oynamaları sağlanmalı

- Halkın afet konusunda bilgi düzeyi yıllara göre düzenli olarak ölçülmeli ve eksiklikler eğitim faaliyetleri, dikkat çekici reklam panolar, afişlerle giderilmelidir.

- Kitlesel göç, küresel salgın ve hastalıklara kadar risk ve tedbir planları hazırlanmalı

- Afetin sadece deprem veya sel gibi olaylarla sınırlı olmadığı konusunda bilinçlendirilme yapılmalidır 
- Afet ya da kriz gibi durumlar oluşmadan önce kentin risk yönetimi iyi planlanmalı bununla birlikte sonrası için oluşan engellenemeyen olası kriz durumlarının giderilebilmesi için bilinçli kriz yönetimi çözüm odaklı olmalı bu konuda afet bilgi sistemi, tehlike haritaları, kentsel riskler ve deprem sigortası gibi unsurlar göz önünde bulundurulmalıdir.

- Etkin bir afet yönetimi için sadece merkezi yönetime bağlı yerel teşkilatlanmalar değil yerel yönetimlerin de aktif şekilde rol almaları sağlanmalıdır.

- Şanlıurfa yaşanan afet olayları bakımından afet illeri arasında yer almalıdır.

- Şanlıurfa ilinde kriz yönetimi kapsamında kurumlar tarafından afete hazırlıklı olabilmek için birtakım masa başı tatbikatlar yapılmalı, olası durumlara karşı senaryolar oluşturulmalıdır.

- Kurum personellerine ve vatandaşlara yönelik acil ve afet durumlarında nasıl hareket etmeleri hususunda eğitici programlar hazırlanarak bu konuda yetişen bilinçli personel sayıs1 artırılmalıdır.

- Şanlıurfa ilinde afet yönetiminin tüm aşamalarında koordineli bir ekip çalışmasıyla tehlikelere karşı yönetilebilmesi için yani olay-komuta zinciri şeklinde bütünleşik bir afet yönetim modeli oluşturulmalıdır.

- Şanlıurfa da afet kültürünün geliştirilmesi, muhtemel risklerin belirlenmesi, afet olaylarının önlenmesine yönelik tedbirlerin alınması, afet konusunda farkındalığın arttırılması için sempozyum, kongre, konferans, panel şeklindeki bilimsel faaliyetler düzenlenmeli ve bu kapsamdaki akademik çalışmalar desteklenmelidir.

\section{KAYNAKÇA}

Afet ve Acil Durum Yönetimi Başkanlığı (AFAD), (2014). Açıklamalı Afet Yönetimi Terimleri Sözlüğ̈̈. Ankara.

Arslan, İ., ve Karagül, S., (2020). Küresel Bir Tehdit (Covid-19 Salgını) ve Değişime Yolculuk, Üsküdar Üniversitesi Sosyal Bilimler Dergisi, say1: 10, (Mayıs 2020): 1-36, http://doi.org/10.32739/uskudarsbd.6.10.67

Bulut, Y, Akın, S. ve Kara, M., (2017). Afet yönetiminde kapasite geliştirmenin önemi ve Hatay açısından bir değerlendirme. Yüzüncü Yıl Üniversitesi Sosyal Bilimler Enstitüsü Dergisi 1(4) elektronik özel sayı.

Bulut, Y. ve Kara, M., (2016). Etkin Bir Afet Yönetiminde Merkez-Yerel İlişkilerinin Önemi: Hatay'da Bir Uygulama. Kamu Yönetimi Sempozyumu, ed. Z. Toprak Karaman, Y. E. Özer, İ. G. Yontar ve G. Teknikler, 10.bs, İzmir: Dokuz Eylül Üniversitesi, 1042-1080. 
Büyükkaracığan, N. (2016). Türkiye' de yerel yönetimlerde kriz ve afet yönetim çalışmalarının mevzuat açısından değerlendirilmesi. Sosyal ve Teknik Araştırmalar Dergisi Sayı:12 ss.195-219

Cumhurbaşkanlığı Kararnamesi (2018). Bakanlıklara Bağll, İlgili, İlişkili Kurum Ve Kuruluşlar İle Diğer Kurum Ve Kuruluşların Teşkilatı Hakkında Cumhurbaşkanlı̆̆ Kararnamesi, https://www.mevzuat.gov.tr/MevzuatMetin/19.5.4.pdf (Erişim Tarihi: 02.06.2021).

Çelik, A . (2014). Sosyal Belediyecilik Anlayışı: Şanlıurfa Büyükşehir Belediyesi Örneği. Gazi Üniversitesi İktisadi ve İdari Bilimler Fakültesi Dergisi, 16(1), 1-20. DOI: 10.26745/gaziuiibf d.300852

Çelik, G. ve Yıldırım, U. (2016). Sığınmacıların Türkiye'de yaşadıkları Kente Uyum Süreci Üzerine Bir Alan Araştırması: Şanlıurfa Örneği. H. M. Paksoy, K. Sarıçoban, E. Yıldırımc1, Ö. Özkan (Ed.), Uluslararası Ortadoğu Konferanslart: Ortadoğu'daki Çatışmalar Bağlamında Göç Sorunu Bildiri Kitabı içinde ss.238-358).

Darıcı, S. (2021). Birecik-Halferi yolu heyelan nedeniyle trafiğe kapandı. Anadolu Haber Ajans1: 29.08.2021, https://www.aa.com.tr/tr/gundem/birecik-halfeti-yolu-heyelannedeniyle-trafige-kapandi/2349990 (Erişim Tarihi: 06.09.2021)

Dinçer, Ö. (2013). Stratejik Yönetim ve İsletme Politikası. İstanbul: Alfa yayınları.

Ergünay, O. (2005). Afet yönetiminde işbirliği ve koordinasyonun önemi, afet yönetiminin temel ilkeleri,(Ankara: JICA Türkiye Ofisi.

Gümüşçü M., Özcan N., Kaya N. (2004). “Şanlıurfa'da Betonarme Yapıların Mevcut Durumu”, TMH -Türkiye Mühendislik Haberleri Sayı 434 - 2004/6 ss. 41-48

Ircan, M. R., \& Duman, N. (2021). Standartlaştırılmış Yağış İndisi (SYİ) Yontemi ile Şanlıurfa ili kuraklı analizi. Cografya Dergisi, 42, 1 18.https://doi.org/10.26650/JGEOG2020-0070

Satterthwaite D. (2020). An Urbanising World, İnternational İnstitute for Enviroment and Development (İIED), https://www.iied.org/urbanising-world(Erişim Tarihi: 05.09.2021).

Kadığlu, M. (2008). Bütünleşik Afet Yönetimin Temel İlkeleri. Afet Zararlarını Azaltmanın Temel İlkeleri, ed. M. Kadığlu ve E. Özdamar, Ankara: Türkiye Ofisi Yayınları

Kamer H. (2021). Güneydoğu'da kuraklık: 'Sofralar çok kötü etkilenecek, acilen afet bölgesi ilan edilmeli https://www.bbc.com/turkce/haberler-turkiye-57021336 (Erişim Tarihi 18.06.2021).

Karaman, Z. T. (2017), Afet yönetimine giriş ve Türkiye'de örgütlenme, bütünleşik afet yönetimi, (Ed. Zerrin Toprak Karaman, Asuman Altay), İzmir: Birleşik Matbaacılık

T.C. İç İşleri Bakanlığı Göç İdaresi Genel Müdürlüğü (2021). Geçici Koruma Kapsamındaki Suriyelilerin Illlere Göre Dă̆llımı, https://www.goc.gov.tr/gecici-koruma5638 (Erişim Tarihi: 05.10.2021). 
Okay A. ve Okay, A., (2002). Halkla Ilişkiler Kavram, Strateji ve Uygulamaları, Der Yayınları: İstanbul

Övgün, B. ve Gül, H. (2019). Kriz yönetiminde reform. Dirençlilik Dergisi 3(2) ss.173-181.

Papuç, M. (2010). Acil Yardım Ve Afet Yönetiminde Çağdaş Yaklaşımlar, İstanbul Üniversitesi Açık Ve Uzaktan Eğitim Fakültesi.

Sepetçioğlu, M. Y. (2013) Şanlıurfa İli Taşkın Sorunları ve Çözüm Önerileri, E-Journal of New World Acedemy, ISSN: 1306-3111

Şahinal, M. S. (2007). Nedenleri ve Sonuçlarıyla Şanlıurfa'da Yaşanan Sel Felaketleri, Türk Coğrafya Dergisi, Sayı:49, ss.89-122

Şaroğlu, F., Emre, Ö. ve Boray, A (1987). Türkiye’nin diri faylarl ve depremsellikleri. Ankara: Maden Tetkik ve Arama Genel Müdürlügü Raporu.

Türkiye Büyük Millet Meclisi (TBMM), (1999). Meclis Araştırma Komisyon Raporu, 21.Dönem, 2.Yasama Yı11, S. Sayıs1: 308. Ankara.

TDK, (2011). Türk dil kurumu Türkçe sözlüğ̈̈, Ankara: Türk Dil Kurumu Yayınları.

Tekin, Ö. F., (2015). Kriz Yönetimi ve kamu yönetimi için önemi. Selçuk Üniversitesi Sosyal Bilimler Meslek Yüksekokulu Dergisi 18(2) (2015): 119-135.

Türkiye İstatistik Kurumu (TÜİK) (2021). Coğrafi İstatistik Portal1-Toplam Nüfus, https://cip.tuik.gov.tr/, (Erişim Tarihi: 04.09.2021).

TÜİK (2020). https://data.tuik.gov.tr/Bulten/Index?p=Uluslararasi-Goc- Istatistikleri-201933709(Erişim Tarihi: 13.07.2021)

United Nation Office for Disaster Risk Reduction (UNDRR) (2019) 2018:Extreme weather event effected 60 million people, https://www.unisdr.org/archive/63267(Erişim Tarihi: 05.09.2021).

Urfa Fanatik Haber Sitesi (2019). Birecik'te Bir Haftada Aynı Yerde İkinci Heyelan. https://www.urfanatik.com/haber/3484294/birecikte-bir-haftada-ayni-yerde-ikinciheyelan (Erişim Tarihi: 04.07.2021)

Tutar, H. (2004). Kriz ve Stres Yönetimi. Ankara: Seçkin yayıncılık.

Yahmed, S. B. (1994). Population growth and disasters. World health 47(3) ss. 26-27.

Yaman, M. ve Düger, Y. (2017). Afet yönetiminde kavramsal çerçeve ve Türkiye'de afet yönetiminin genel tarihsel gelişimi. Afet yönetimi, ed. Ö. Önder ve M. Yaman. Bursa: Ekin basın yayın dağıtım.

Yavaş, H (2001). Doğal Afetler ve Kriz Yönetimi. Yerel Yönetim ve Denetim Dergisi, Cilt:6, Sayl:2, ss. 50-55.

Yavuz Ö. (2014). Afetler Sonrası Yapılan Sosyal Yardımlar ve Hizmetler, İstanbul: İdeal Kültür Yayıncılık. 